\title{
How do service quality, experiences and enduring involvement influence tourists' behavior? An empirical study in the Picasso and Miró museums in Barcelona
}

\begin{abstract}
Visit experience, service quality, and involvement have been previously identified as antecedents of behavioral intentions regarding tourism attractions. Nevertheless, previous studies have paid little attention to these variables from an integrative perspective. This paper develops an integrated model that examines how service quality, perceived experiences and enduring involvement determine tourists' behaviour. The model proposes that enduring involvement has both a direct and moderating influence on tourists' behavioural intentions and loyalty. Data were collected from 1,091 visitors of two world-class museums in the city of Barcelona: the Picasso Museum and the Miró Foundation. The results suggest that visit experience, service quality, and involvement are drivers of satisfaction, and that satisfaction influences the behavioral intentions of visitors to the museum. In addition, the visitors' level of art involvement negatively moderates the influence of perceived quality and experience on tourists' satisfaction.
\end{abstract}

Keywords: visit experience, service quality, involvement, satisfaction, behavioral intentions, museum 


\section{INTRODUCTION}

Visiting museums is one of the most popular tourist activities undertaken by tourists during their visits to cities. The museums of the city of Barcelona (Catalonia, Spain) received 12,485,216 visitors in 2014 (Barcelona Tourism, 2015). To arouse the interest of such a number of tourists, museums are currently focusing on providing their visitors with experiences and high-quality services. As regards to experiences, tourist products and services should be created to be entertaining, educational, aesthetic, and as an escape from the daily routine. In fact, the activities that tourists do at a destination can be categorized as an experience (Oh et al., 2007). In addition, museums, together with other tourist attractions, are closely related to visitors' needs for high-quality services (De Rojas \& Camarero, 2008).

Previous research suggests that service quality and experiences have been critical for visitors to enhance tourists' satisfaction and achieve favorable behavioral and patronage intentions (Lee et al., 2004; Loureiro \& González, 2008; Clemes et al., 2011; Kim et al., 2012). When tourists perceive destinations as providing fulfilling experiences and high-quality services and infrastructures, they tend to develop more favorable attitudes to the destination image and to continue visiting it in the future (Beerli \& Martín, 2004). As indicated by Song et al. (2011), improving tourist satisfaction is critical not only for tourism attractions but also for destinations. Higher levels of tourist satisfaction are likely to enhance reputation for both service providers and the destination as a whole. Furthermore, tourists' behavior literature indicates that an improvement in these satisfaction levels may contribute to increase consumer loyalty (Huang et al., 2012; Eusébio \& Vieria, 2013; Jin et al., 2015). Consequently, a better understanding of service experience and quality in museums as drivers of both customer satisfaction and 
behavioral intentions is especially important to allow museum managers to better design their tourist products and services (Chen \& Chen, 2010).

Previous studies have also identified leisure involvement as an antecedent of consumer behavior, especially in the context of outdoor activities (Kyle et al., 2004; Kyle et al., 2007; Chang \& Gibson, 2011; Cheng \& Tsaur, 2012). However, and to the best of our knowledge, no study has examined the role of art involvement in a model of tourist behavioral intentions for museums, where visit experience, service quality, and satisfaction are drivers of behavioral intentions. Besides, while most previous research considers that enduring involvement directly determines individuals' judgments about a tourist activity (Lu et al., 2015), other authors suggest that this variable moderates the impact of customers' cognitions on tourist satisfaction (Chen \& Tsai, 2008). To fill this gap in the literature and in the museum context, this study aims to analyze simultaneously both the direct and moderating effect of enduring involvement.

Considering these literature gaps, the aim of this study is twofold. First, it aims to analyze how tourists' experiences, perceived service quality and involvement directly affect their levels of satisfaction and behavioral intentions in the museum context. Second, it aims to explore the moderating effect of tourists' enduring involvement in satisfaction. Specifically, it is proposed that the influence of perceived experiences and service quality in satisfaction is weaker for highly involved tourists. To reach these aims, the study designs and tests an integrative model where the direct and moderating effects are examined. 


\section{LITERATURE REVIEW}

\section{Behavioral intentions}

Behavioral intentions are the readiness and/or the likelihood of an individual exhibiting a specific behavior (Ajzen, 1991). This behavior suggests the intention to offer positive or negative recommendations about a company and the intention to repurchase its products or services (Zeitahml et al., 1996). Oliver's (1999) conceptualization on loyalty suggest that loyal individuals show higher levels of commitment towards a company. This commitment implies a transition from a favorable willingness to re-buy a company's product or service to the actual purchase behavior. This loyalty sequence is frequently classified in several phases according to the customer's levels of commitment. These stages are the cognitive, affective, conative, and action phases. Favorable behavioral intentions frequently represent the conative stage of loyalty that researchers refer to as behavioral intentions (Chen \& Chen, 2010). Specifically, in this stage, the consumer is willing to repurchase the product or service, but this is still an unrealized action (Oliver, 1999). According to Tsai (2016), the objective beliefs on a behaviour and subjective emotions on it influence the individual's overall attitude towards such behavior. However, the individual's actual behavior is mainly determined by the behavioral intention. Consequently, behavioral intention is normally considered as an effective method for predicting an individual's actual behavior since these variables are highly correlated (Ajzen, 1991). Coherently, in this study, following previous research, behavioral intentions such as revisit intentions and WOM recommendations will be addressed. 
In most tourism studies this conative stage has been used as an attitudinal loyalty, the so-called behavioral intentions (Chen \& Chen, 2010). Indeed, literature in tourism has used repurchase/revisit intentions and word-of-mouth (WOM) as specific forms of behavioral intentions (Palau-Saumell et al., 2013, 2014). Previous research suggests that customers' positive experiences on tourism services increase repeated visits what leads to positive WOM (Chen \& Tsai, 2007; Lee et al., 2010). WOM is considered the most determinant and reliable source of information for potential tourists (Williams \& Soutar, 2009). Previous empirical studies in tourism identify different antecedents of behavioural intentions, including satisfaction, experiences, perceived quality and tourists' involvement (Chen et al., 2011; Jin et al., 2015; Tsai, 2016; Wong \& Tang, 2016). Specifically, several studies show a high correlation between tourist satisfaction, perceived quality and behavioural intentions in the context of tourism (Loureiro \& González, 2008; Chen et al., 2011; Prayag et al., 2013; Jin et al., 2015). Furthermore, the role of experience has gained a critical relevance in explaining behavioral intentions in tourism (Wang et al., 2012; Ali et al., 2016; Tan, 2016). For instance, recently, Ali, Kim et al. (2016) empirically studied the relationship between visitors' experience, overall satisfaction and their loyalty towards a leisure attraction. The findings suggested that tourists' experiences regarding interactions with the physical setting, the employees or other customers determine the overall assessment of the destination and the willingness to revisit it. Additionally, other studies suggest that personal involvement affects customers' loyalty in various tourism sectors like sport events (Brown et al., 2016; Wong \& Tang, 2016), cultural and heritage destinations (Shen et al., 2009) or leisure activities (Chang \& Gibson, 2015). 


\section{Satisfaction}

The cognitive-affective approach, which is the one used in this study, introduces the idea that the consumers' satisfaction is determined by their cognitive judgments about the consumption experience. Thus, the loyalty or behavioral intentions are the essential consequence of satisfaction (Brady \& Robertson, 2001).

The relationship between satisfaction and loyalty is classic in consumer behavior studies and has been widely tested (Bolton \& Lemon, 1999; Forgas et al., 2010, 2011; Olsen et al., 2005) also in tourism (Campo \& Yagüe, 2008; Yuan \& Jang, 2008; Hyun, 2010; Forgas-Coll et al., 2012). Satisfaction has been considered as an antecedent of behavioral intentions by a plethora of studies in different tourism sectors, such as: rural lodging (Loureiro \& González, 2008), heritage (Chen \& Chen, 2010; Palau-Saumell et al., 2013), visits to National Parks (Chen et al., 2011) or festivals (Yoon et al., 2010). Specifically, the literature has proved that satisfaction elicits customers' loyalty at the conative stage of behavioral intentions (He \& Song, 2009; Williams \& Soutar, 2009). Consequently, if overall satisfaction is high, the tourist will be more likely to engage in positive WOM behaviours with friends and relatives and to revisit the tourist destination or attraction in the future (Tian-Cole et al., 2002). This happens because tourists tend exhibit risk-minimizing behaviors given the considerable monetary sacrifice that touristic activities usually involve (Hultman et al., 2015). Consequently, more satisfied tourists will be more likely to revisit tourist destinations or attractions in the future and to speak favorably of a visited destination to their social circle.

However, the literature regarding the relationship between satisfaction and behavioral intentions is scarce in the museum sector. There is an exploratory study conducted by Harrison and Shaw (2004) on a small metropolitan museum in Australia. 
In this study the authors found that visitors who were satisfied expressed a stronger willingness to recommend the museum. Nowacki (2009) also found this positive relationship. However, they measured satisfaction by using an emotional semantic differential scale, and, in addition, the sample involved visitors to museums and one zoo in Poland. Camarero et al. (2011) concluded that satisfaction had a positive and direct influence on behavioral intentions in a small sample of "friends of the museum". Thus, due to the scarcity of research on the museum sector, the following hypothesis is proposed:

Hypothesis 1: Tourist satisfaction with the museum directly and positively influences behavioral intentions.

\section{Visit experience}

Tourism is a rich context to explore the ways in which tourists construct relevant experiences (Bosangit et al., 2015). This experience is a phenomenon that involves different psychological abilities related to the experience of visiting a place (QuinlanCutler et al., 2014).

There is no consensus among researchers on how to measure experience, and different dimensions have been used to study customer experiences. Pine and Gilmore (1999) proposed that experience may be categorized as entertainment, education, escapism, and aesthetic. Huang et al. (2012) adopted these dimensions to test the relationship between experiences, post-emotions and satisfaction in a sample of visitors to a cultural performance in Guilin, China. Moreover, Mason and Paggiaro (2012) developed an emotional point of view of the experiences, and Wang et al. (2012) found 
only three experience dimensions - aesthetic, emotional, and action - in a study of visitors to three National Parks in China. Other researchers like Kang and Gretzel (2012), identified learning, enjoyment and escape as dimensions of the tourist experience, which are the dimensions used in this study. They found that the experience influenced attitudinal stewardship among visitors to a National Park in Texas, United States.

Learning experience means that tourists acquire new knowledge and new skills (Pearce, 2005). Enjoyment experience is the emotional perception of the tourist during the trip or visit (Davis et al., 1992). Escape refers to the feeling that the tourist has of living aside from the concerns of daily life (Pearce, 2005).

In their study of a world heritage village, Beeho and Prentice (1997) established that tourists who are satisfied with their recreational experiences recommend them to friends and relatives. Wang et al. (2012) noted the role of experience in influencing the behavioral intentions of visitors to wetland parks. Other researchers like Sheng and Chen (2012) analyzed experiences in the museum sector. These authors developed and validated an expectations experience scale. However, they did not explore the relationships between the perceptions of the visitors' experience with satisfaction and behavioral intentions. Based on the above review and discussion from the literature, the following hypotheses were proposed:

Hypothesis 2: Tourist experience with the museum is directly and positively related to satisfaction.

Hypothesis 3: Tourist experience with the museum is directly and positively related to behavioral intentions. 


\section{Service Quality}

Service quality has been defined as an overall judgment of service by customers (Ganguli \& Roy, 2010), or an assessment process, in which the visitor contrasts his expectations with his perception of the service obtained (Grönroos, 1984). Several scales of service quality have been developed by researchers, but there is no consensus on the exact nature and content of these dimensions of service quality (Kang, 2006). Two of the most commonly used are SERVQUAL and the Grönroos model.

SERVQUAL (Parasaruman et al., 1988) is the most widely-known scale of service quality. It measures the difference between expectations and perceptions. It has been criticized, however, because it focuses on the service-delivery process (Richard \& Allaway, 1993). This led Cronin and Taylor (1992) to create their SERVPERF scale, which measures the same dimensions as the SERVQUAL, but uses only the performance measure. Other researchers have modified the SERVQUAL dimensions by adding new constructs in order to allow it to accommodate for uniqueness of different types of service settings (Ganguli \& Roy, 2010).

The Grönroos model (Grönroos, 1984) identifies two dimensions of service quality: a technical dimension - what a customer receives from a service - and a functional dimension - the way a service is delivered to a customer. Several authors have utilized the Grönroos service quality model in different service contexts (Reichel et al., 2000; Kang \& James, 2004; Lundahl et al., 2009). Prior literature on museum management has also developed some scales of service quality. Nowacki (2005), and Maher et al. (2011) adapted the SERVQUAL scale. Nevertheless, these studies cannot generalize the results because they used small samples to validate them, the context was highly specialized, and the results were specific to each case. In this paper, given the lack of 
consensus in prior research to measure service quality in the museum contexts, we use a measurement instrument that combines items both from the technical and functional dimensions. In fact, some authors posit that the SERVQUAL dimensions are different according to the type of service or the country considered (Samen et al., 2013). While the technical dimension seem to have a higher weight in visiting a museum, the subjective feelings perceived by visitors must also be considered when assessing the overall visit (Martín-Ruiz et al., 2010).

The relationship between service quality and satisfaction has been found in a study of a historical interpretation center (De Rojas \& Camarero, 2008). Additionally, some studies have found a direct relationship between service quality and satisfaction, and a direct relationship between service quality and intentions in the tourism contexts (Loureiro \& González, 2008). Based on a review of previous research findings, and due to the scarcity of research in the museum sector, the following hypotheses were proposed:

Hypothesis 4: Service quality of the museum is directly and positively related to tourist satisfaction.

Hypothesis 5: Service quality of the museum is directly and positively related to tourist behavioral intentions.

\section{Enduring involvement}

Involvement with a leisure activity represents the perceptions that an individual has on the level of commitment to such activity (Beaton et al., 2009). Houston and Rothschild 
(1978) categorized involvement as response, situational, and enduring involvement. Enduring involvement, which is the category of involvement employed in this study, involves people engaging in and paying attention to a specific situation, object or thing for relatively long periods of time (Huang et al., 2010). It refers to a person's constant preoccupation with an activity, which has a special meaning for him/her (McIntyre, 1989). Our research mainly focuses, with respect to involvement, on the visitors' involvement in art activities.

There is no consensus among researchers about the dimensions of involvement. Many researchers have investigated various aspects of involvement using different conceptualizations (Kyle et al., 2007; Chang \& Gibson, 2011), because people have different degrees of interest, participation, and self-concept (Chang \& Gibson, 2011). According to Kyle et al. (2007), the dimensions that have received strongest support by the literature have been those connected to McIntyre's dimensions, i.e., attraction, centrality, and self-expression. These were the dimensions considered for this study. Attraction indicates the importance of enjoyment and satisfaction achieved through an activity. Self-expression encompasses issues of self-identity and social identity related to the activity. Centrality refers to the degree to which an individual's life is centered on the activity (McIntyre, 1989).

Understanding the critical role of enduring involvement in tourists' judgements and intentions is critical in the context of cultural tourism. As indicated by Lu et al. (2015), the relationship between tourists' involvement and their assessment on the destination image in cultural and heritage tourism remains unclear and yet to be investigated. Previous research indicates that involvement is directly related to individuals' satisfaction with an activity and to behavioral intentions. Tourist involvement has been 
positively associated with satisfaction in a study conducted on a historic district in China (Lu et al., 2015), or satisfaction with trip experience (Kim et al., 2015), and with the satisfaction and loyalty of wine tourists (Lee \& Chang, 2012). In the context of cultural tourism, Kolar and Zabkar (2010) show that tourists' evaluations on a cultural attraction depends on their cultural motivation, understood as a set of intellectuallybased interests in in culture, history and heritage. They found that the larger the cultural motivation of the tourist, the higher the perceived authenticity of the attraction and the loyalty towards it. Hou et al. (2005) also showed a positive relationship between enduring involvement and destination attractiveness in the context of a cultural tourism destination. Nonetheless, there are no specific studies testing these relationships in the museum sector. So based on the exposition of the prior literature, the following hypothesis is propsoed:

Hypothesis 6: Involvement in art activities is directly and positively related to satisfaction.

Hypothesis 7: Involvement in art activities is directly and positively related to behavioral intentions.

Several researchers have postulated that involvement may also play a moderating role in the process of consumer behavior and decision-making, and most of them have found differences in consumer attitudes between groups of high and low involvement (Hou et al., 2005; Suh \& Yi, 2006). According to Prentice et al. (1998) there may be differences in the influence of personal experiences on tourists' evaluations between highly involved cultural tourists and low-involvement ones. These authors reported that while less experience visitors to cultural attractions are more influenced by cognitive 
experiences, meaningful symbolisms are more relevant for more experienced and culturally motivated visitors. Özel and Kozak (2012) also suggest that, in practice, different segments of cultural tourists can be identified and that their experiences are not equally affected by the same motivations. In fact, Shaffer and Sherrell (1997) used the social judgment theory to indicate that high-involvement individuals show more extreme evaluations because it is related with an extended latitude of rejection, whereas low involvement is associated with an expanded zone of indifference. Higher involvement groups are associated with higher expectations prior to product use (Oliver \& Bearden, 1983). The elaboration likelihood model (ELM) posits that individuals under high-involvement conditions are more motivated to dedicate the cognitive effort to evaluate the true merits of an activity, service, or product. In contrast, the attitude of the low-involvement individuals is less affected by argument quality (Petty et al., 1983). However, previous literature confirms that the influence of involvement depends on the context and the activity. Prior research (Chen \& Tsai, 2008; Palau-Saumell et al., 2014) has found that the influence of low-involvement groups is stronger than that of highinvolvement groups in the relationship between cognitive and attitude variables when the expectation of a consumer is less than the result obtained in the consumption of a product or a service. Therefore, in a museum of artists such as Picasso and Miró, visitors more involved in art activities are more likely to be less satisfied with the experience and the quality of the visit that the less involved. Thus, based on the above discussion, two hypotheses are proposed: 
Hypothesis 8: Service quality has a stronger positive effect on tourist satisfaction when the level of involvement in art activities is low than when the level of involvement is high.

Hypothesis 9: Visit experience has a stronger positive effect on tourist satisfaction when the level of involvement in art activities is low than when the level of involvement is high.

Figure 1 illustrates the theoretical model by integrating the hypotheses proposed.

\section{INSERT FIGURE 1}

\section{METHODOLOGY}

\section{Data collection}

To test the hypotheses, we gathered data from an on-site sample of tourists of two important art-related museums in the city of Barcelona. Both are part of the main tourist attractions of the city.

Specifically, personal interviews were carried out at the Miró and Picasso museums between April and May 2014. The Picasso Museum in Barcelona is an international reference for understanding the formative years of the painter, Pablo Picasso (1881-1973), one of the greatest representatives of the cubist movement. The Museum was opened in 1963, and its permanent collection contains 4,251 paintings, sculptures, and ceramic pieces (Picasso Museum, 2015), and it is visited by 919,814 visitors per year (Barcelona Tourism, 2015). The Miró Foundation was created by the 
surrealist painter, sculptor, and ceramist Joan Miró (1893-1983) in 1975 with works from his own private collection and a desire to set up an internationally recognized center in Barcelona to make the collection known to the public, as well as being a contemporary art research center (Miró Foundation, 2015). Every year 489,928 visitors visit the Foundation (Barcelona Tourism, 2015).

The interviews were performed with national and international tourists of these museums. The interviewers were four students in the last year of an undergraduate course in Tourism Management. These students were enrolled in a course of Tourism Marketing and received specific training to carry out the interviews. The interviewers waited in a public area at the exit of the museums in order to conduct the survey when tourists had just finished their visit to these attractions. Both English and Spanish versions of the questionnaires were available. After discarding incoherent and incomplete questionnaires, 1,091 surveys were considered valid. 545 questionnaires were gathered for the Picasso Museum and 546 for the Miró Foundation. Visitors were guaranteed confidentiality and anonymity of the information provided.

As regards the sample composition, $55.3 \%$ of the respondents were female and 44.7\% male. $47.5 \%$ were national tourists, and $52.5 \%$ were foreign tourists. $19.8 \%$ of the sample were aged between 18 and 24 years, $18.8 \%$ were between 35 and 44 years old, and $19.3 \%$ were between 45 and 54 . Almost $22 \%$ of the respondents were 55 or older. $85.9 \%$ had a medium or higher college degree. $14 \%$ stated that their incomes were below the average in their countries, $55.6 \%$ said that their incomes were around the average, and $30.3 \%$ had incomes above the average. 


\section{Variables measurement}

To measure the different variables we employed 5-point multi-item Likert scales $(1=$ strongly disagree; $5=$ strongly agree) that had been validated in previous studies. Behavioral intentions were measured with three items adapted from Lee et al. (2007). Satisfaction was measured with four items from Forgas-Coll et al. (2012). With respect to the perceived experience, we employed three dimensions based on the work of Kang and Gretzel (2012). Specifically, we considered experience as a second-order factor composed of the first-order dimensions learning, enjoyment, and evasion. Each of these dimensions was measured with two items. Perceived quality was measured with six items from Martin-Ruíz et al. (2010). Involvement was measured with the three dimensions proposed by Chang and Gibson (2011). This construct was also considered as a second-order factor construct composed of the attraction, self-expression, and centrality dimensions. Attraction and centrality were measured with three items, while self-expression was measured with four items. Appendix 1 shows the measurement scales.

\section{RESULTS ANALYSIS}

To assess the causal effects between the latent variables, we employed structural equation modeling with SMART-PLS. The use of PLS is preferable when the model is incremental, complex, includes a large number of indicators and latent variables, or combines different theoretical approaches (Chin, 2010; Hair et al., 2011). 


\section{Analysis of the measurement model}

Since PLS does not estimate models including second-order constructs directly, we created them through the two-step approach (Wetzels et al., 2009). This initial estimation allowed us to obtain the latent variable scores for the first-order latent variables that would be used in the estimation of the second-order factor model, and to assess the validity and reliability of the measurement model according to the reliability, and convergent and discriminant validity criteria. The initial estimation revealed that the factor loadings were above or slightly below the recommended level of 0.7 , thus confirming individual reliability. The composite reliability of the survey instrument was also confirmed by calculating the scales Cronbach's Alpha and the Composite Reliability Index. These indexes were above the suggested benchmarks of 0.7 (Nunnally \& Bernstein, 1994). The constructs also met convergent validity criteria, since the average variance extracted (AVE) values were above 0.5. Results of the measurement model are shown in Table 1.

\section{INSERT TABLE 1}

The existence of discriminant validity was verified using the criteria of Barclay et al. (1995) and Henseler et al. (2015). The first compares the square root of the AVE from each latent variable with the estimated correlations for every pair of variables. The second involves examining the heterotrait-monotrait ratio of correlations (HTMT) between the latent variables. Since our estimation revealed that the square root of the AVE from each latent variable was larger than the estimated correlations for all pairs of 
variables and that the HTMT values were below the recommended threshold of 0.90 , we can confirm that discriminant criteria are met (Table 2).

\section{INSERT TABLE 2}

\section{Analysis of the structural model}

Once the latent scores of the first-order model had been obtained, we proceeded to estimate the second-order factor model. We assessed the significance of the path coefficients with a bootstrapping procedure with 5,000 subsamples. Moreover, we calculated the moderating effects by employing the product-indicator approach. This approach is preferable when the scope of the research focuses on finding an estimate for the true parameter of an interaction effect, thus describing the relations in situations of a large number of observations (Henseler \& Chin, 2010). The model explained $68.1 \%$ of satisfaction and $64.4 \%$ of behavioral intentions. The predictive relevance of the model was also assessed through the Stone-Geisser test. This showed that the Q2 value of this test for the predicted variables was positive $(\mathrm{Q} 2-\mathrm{SAT}=0.522 ; \mathrm{Q} 2-\mathrm{INT}=0.526)$. Results of the structural model are shown in Table 3.

The PLS analysis revealed that, as expected, tourist satisfaction with the museum visit significantly influenced favorable behavioral intentions $(\beta=0.574 ; \mathrm{t}=19.335)$. This result provides us with support for Hypothesis 1. Perceived experience also significantly affected tourist satisfaction $(\beta=0.477 ; \mathrm{t}=16.334)$ and behavioral intentions $(\beta=0.132$; $\mathrm{t}=4.429$ ), thus supporting Hypotheses 2 and 3. Hypotheses 4 and 5 were also confirmed. Structural parameters were positive and significant, and suggested that tourist perceptions about the service quality of the museum influence their satisfaction 
$(\beta=0.275 ; \mathrm{t}=10.801)$, and behavioral intentions $(\beta=0.087 ; \mathrm{t}=3.353)$. As regards the role of involvement, the estimations confirm that more involved individuals were more satisfied with their visits $(\beta=0.180 ; \mathrm{t}=7.041)$, and manifested more favorable behavioral intentions $(\beta=0.144 ; t=5.644)$, thus supporting Hypotheses 6 and 7. However, beyond the direct effects of involvement on satisfaction and behavioral intentions, the estimations indicate that personal involvement with the arts moderates the influence of experience and perceived service quality on the tourist satisfaction judgments.

Regarding these moderating relationships, results suggested that involvement negatively moderates the influence of experience $(\beta=-0.056 ; t=3.160)$ and quality on satisfaction $(\beta=-0.085 ; t=5.039)$. In other words, the higher the personal involvement of the tourist with the arts is, the lower the impact of the perceived experience and service quality on the tourist overall satisfaction with the museum will be.

\section{INSERT TABLE 3}

\section{DISCUSSION AND CONCLUSIONS}

The research found that satisfied tourist will be more likely to exhibit more favorable behavioral intentions towards the museum by revisiting it or by carrying out patronage intentions (i.e., positive WOM). Tourist satisfaction has strongly attracted researchers' and practitioners' attention because of its great potential to influence favorable postpurchase behaviors. In spite of the fact that satisfaction with the museum visit itself may not be enough to generate revisit situations, in today's competitive scenarios it is important for managers in this sector to pay attention to tourist overall satisfaction with 
the museum. This will allow them to create the optimum conditions to favor positive post-purchase behaviors in the form of intentions to revisit and WOM.

Furthermore, this study revealed that both tourist perception on the museum's service quality and their visit experience directly influenced behavioral intentions. Thus, findings from this research highlight that developing tourists' revisit intentions, and WOM depends not only on the museum's ability to increase visitors' satisfaction, but also on its ability to provide high-quality services that are valued by visitors, and to create an experience that allows visitors to enjoy, learn, and disconnect. The study also suggests that those tourists who considered the museum services to be high-quality and those that perceived the visit as a positive experience were also more satisfied with the museum. Consequently, quality and experience directly and indirectly influence behavioral intentions through tourist satisfaction. Greater levels of service quality and visit experience indirectly encourage patronage and revisit intentions by increasing satisfaction associated with the attraction. It is therefore clear that the roles of quality and experience are far more complex than previously reported (Cronin et al., 2000; Tian-Cole \& Crompton, 2003). Not only does service quality and experience affect satisfaction, it also directly predicts behavioral intentions. This result would be suggesting that there may be other indirect effects involved in these relationships, such as perceived value.

This research also reveals that the magnitude of the effect of the visit experience on the tourist satisfaction and on their behavioral intentions is stronger than the influence of service quality. This result has a major implication for museum managers, since they should direct their efforts to understanding tourist evaluations of the museum experience and perceptions. Previous research indicates that both cognitive and 
affective approaches explain how satisfaction derives from quality received and from stimuli that leverage visitors' experience and emotions (De Rojas \& Camarero, 2008). Our study supports this dual cognitive-affective approach to explain individuals' evaluations and behavioral intentions. However, our findings go a step further by suggesting that in the context of arts and cultural exhibitions the experience undergone during the service encounter has a stronger impact on tourists' behaviors than quality perceptions. According to Goulding (2000), museums are social settings and the experience should be designed to trigger emotions and to maximize engagement during the visit. Therefore, if an art exposition is designed as a stimulating, appealing and instructive activity, feelings of pleasure, enjoyment, immersion or cognitive absorption may arise, thus affecting visitors' evaluations.

As regards the consequences of involvement, the findings from the study suggest that this variable has a positive effect on overall satisfaction and on behavioral intentions. Within this context, we provide support for other studies such as Kyle et al. (2004) regarding the relevance of understanding the personal involvement of leisure consumers. Specifically, we found that the higher the level of tourists' personal involvement with the arts is, the more satisfaction and positive behavioral intentions are likely to be increased. Furthermore, the findings of our research reveal that involvement moderates the influence of perceived quality and visit experience on overall satisfaction. Specifically, the results indicate that the higher the level of personal involvement with the arts is, the more attenuated the influence of perceived quality and experience on the visitors' assessment of the museum will be. Under low elaboration conditions, visitors tend to use simple methods to judge objects. In such cases, low-involved visitors may base their judgment on simple cues related to perceived quality and experience (e.g., site 
employees' responsiveness, information quality, accessibility, educational orientation of the exhibition, etc.). In other words, when the art is not a relevant part of the individual's self-concept, the impact of the quality and the experience on his or her judgments is stronger than for those individuals who are inherently interested in these activities. High involvement, on the other hand, might attenuate the relationship between quality, experience, and satisfaction.

The results on the moderating effect of enduring involvement are especially relevant in the museums sector considering the nature of the experience. This subjective experience may be different from "culture tourists", that are inherently highly motivated to visit these tourist attractions, to "museums visitors", who perform these activities as a complementary part of their holidays. According to this study's results, more involved cultural tourists are less affected by their perceptions on the visit experience and service quality. This may happen because this type of tourists may have initial high expectations on the museum attractions considering their prior experiences with other cultural sites. Thus, other elements, apart from service quality and visit experience, that contribute to build meaningful symbolisms could be more relevant in leveraging favorable attitudes and behaviors in culturally motivated visitors (Prentice et al., 1998). On the other hand, less experienced and less motivated cultural visitors will be more affected by their initial perceptions on the museums service quality and visit experience. Thus, museums should pay attention to offer functional and technical high quality services and to provide learning-oriented, enjoyable and scape experiences to satisfy these less culturally motivated visitors and promote favorable behavioral and patronage intentions. 


\section{Limitations and future research lines}

This study is not free of limitations. First, the study is limited to two specific museums with particular characteristics, and especially because these museums are part of the tourist promotional activities of the city to cruisers, tour operators, and hotels. It would be beneficial to apply this model in other types of museums with different orientations in other countries and cultures. Second, our research explores behavioral intentions and satisfaction as consequences of quality and experience. Other relevant variables such as trust, perceived value or commitment would contribute to deepen the understanding of how behavioral intentions are formed in tourist activities. Third, the study reveals that quality and experience play a major role in forming low-involved individuals' attitudes. Thus, it would be necessary to analyze what specific variables are more relevant in forming highly involved individuals' judgments. For example, some researchers argue that the relationship between perceived value and satisfaction is reinforced as involvement increases (Chen \& Tsai, 2008). Similarly, in this line, other approaches like social identity theories could contribute to identify relevant factors for highly involved visitors (Cheng \& Tsaur, 2012). For example, it is possible that involved visitors have a stronger sense of connection with an exhibition if this is perceived as a distinctive and prestigious attraction, the identity of which fits in with the visitor's own self-identity.

\section{References}

Ali F, Kim WG, Li J, Jeon HM. 2016. Make it delightful: customers' experience, satisfaction and loyalty in Malaysian theme parks. Journal of Destination Marketing \& Management. http://dx.doi.org/10.1016/j.jdmm.2016.04.003

Azen I. 1991. The theory of planned behavior. Organizational Behavior and Human Decision Processes 50(2): 179-211. 
Barcelona Tourism (2015). Tourism statistics in Barcelona and region, 2014. Available from: http://professional.barcelonaturisme.com/imgfiles/estad/Est2014.pdf (accessed $15 \mathrm{Feb} 2016)$.

Barclay D, Higgins C, Thompson R. 1995. The partial least squares (PLS) approach to causal modeling: Personal computer adoption and use as an illustration. Technology studies 2(2): 285-309.

Beaton AA, Funk DC, Alexandris K. 2009. Operationalizing a theory of participation in physically active leisure. Journal of Leisure Research 41(2): 177-203.

Beeho AJ, Prentice RC. 1997. Conceptualizing the experiences of heritage tourists: A case study of New Lanark World Heritage Village. Tourism Management 18(2): 7587.

Beerli A, Martin J. 2004. Factors influencing destination image. Annals of Tourism Research 31(3): 657-681.

Bolton RN, Lemon KN. 1999. A dynamic model of customers' usage of services: Usage as an antecedent and consequence of satisfaction. Journal of Marketing Research 36(2): 171-186.

Bosangit C, Hibbert S, McCabe S. 2015. "If I was going to die I should at least be having fun": Travel blogs, meaning and tourist experience. Annals of Tourism Research 55(1): 1-14.

Brady M, Robertson C. 2001. Searching for a consensus on the antecedent role of service quality and satisfaction: An exploratory cross-national study. Journal of Business Research 51(1): 53-60.

Brown G, Smith A, \& Assaker G. 2016. Revisiting the host city: an empirical examination of sport involvement, place attachment, event satisfaction and spectator intentions at the London Olympics. Tourism Management, 55: 160-172.

Camarero Izquierdo C, Garrido Samaniego MJ. 2011. Strengthening members' relationships through cultural activities in museums. Journal of Leisure Research 43(4): 560-588.

Campo S, Yagüe MJ. 2008. Tourist loyalty to tour operator: effects of price promotions and tourist effort. Journal of Travel Research, 46(3): 318-326.

Chang S, Gibson HJ. 2011. Physically active leisure and tourism connection: Leisure involvement and choice of tourism activities among paddlers. Leisure Sciences 33(2): 162-181.

Chang S, Gibson HJ. 2015. The relationships between four concepts (involvement, commitment, loyalty, and habit) and consistency in behavior across leisure and tourism. Tourism Management Perspectives, 13: 41-50.

Chen C-F, Chen F-S. 2010. Experience quality, perceived value, satisfaction and behavioural intentions for heritage tourists. Tourism Management 31(1): 29-35.

Chen CM, Lee HT, Chen SH, Huang TH. 2011. Tourist behavioural intentions in relation to service quality and customer satisfaction in Kinmen National Park, Taiwan. International Journal of Tourism Research 13(5): 416-432.

Chen C-F, Tsai D. 2007. How destination image and evaluative factors affect behavioral intentions?. Tourism Management 28(4): 1115-1122.

Chen C-F, Tsai M-H. 2008. Perceived value, satisfaction, and loyalty of TV travel product shopping: Involvement as a moderator. Tourism Management 29(6): 11661171. 
Cheng TM, Tsaur SH. 2012. The relationship between serious leisure characteristics and recreation involvement: A case study of Taiwan's surfing activities. Leisure Studies 31(1): 53-68.

Chin WW. 2010. How to write up and report PLS analyses. In Handbook of partial least squares: Concepts, methods and applications in marketing and related fields, Esposito Vinzi V, Chin WW, Henseler J, Wang H (eds) Springer: Berlin; 655-690.

Clemes MD, Gan C, Ren M. 2011. Synthesizing the effects of service quality, value, and customer satisfaction of behavioral intentions in the motel industry: an empirical analysis. Journal of Hospitality \& Tourism Research 35(4): 530-568.

Cronin JJ, Taylor SA. 1992. Measuring service quality: A reexamination and extension. Journal of Marketing 56(3): 55-68.

Cronin JJ, Brady MK, Hult GTM. 2000. Assessing the effects of quality, value, and customer satisfaction on consumer behavioral intentions in service environments. Journal of retailing 76(2): 193-218.

Davis FD, Bagozzi RP, Warshaw PR. 1992. Extrinsic and intrinsic motivation to use computers in the workplace. Journal of Applied Social Psychology 22(14): 11111132.

De Rojas C, Camarero C. 2008. Visitors' experience, mood and satisfaction in a heritage context: Evidence from an interpretation center. Tourism Management 29(3): 525-537.

Eusébio C, Vieira AL.2013. Destination attributes' evaluation, satisfaction and behavioural intentions: a structural modelling approach. International Journal of Tourism Research 15(1): 66-80.

Forgas S, Moliner MA, Sánchez J, Palau R. 2010. Antecedents of airline passenger loyalty: Low-cost versus traditional airlines. Journal of Air Transport Management, 16(4): 229-233.

Forgas S, Moliner MA, Sánchez J, Palau R. 2011. La formación de la lealtad de un cliente de una compañía aérea: diferencias entre aerolíneas tradicionales y de bajo coste. Cuadernos de Economía y Dirección de la Empresa, 14(3): 162-172.

Forgas-Coll S, Palau-Saumell R, Sáchez-García J, Callarisa-Fiol L. 2012. Urban destination loyalty drivers and cross-national moderator effects: The case of Barcelona. Tourism Management 33(6): 1309-1320.

Ganguli S, Roy SK. 2010. Service quality dimensions of hybrid services. Managing Service Quality 20(5): 404-424.

Goulding C. 2000. The museum environment and the visitor experience. European Journal of Marketing 34(3/4): 261-278.

Grönroos C. 1984. A service quality model and its marketing implications. European Journal of Marketing 18(4): 36-44.

Hair JF, Ringle CM, Sarstedt M. 2011. PLS-SEM: Indeed a silver bullet. Journal of Marketing Theory and Practice 19(2): 139-152.

Harrison P, Shaw R. 2004. Consumer satisfaction and post-purchase intentions: An exploratory study of museum visitors. International Journal of Arts Management 6(2): 23-32.

He Y, Song H. 2009. A mediation model of tourists' repurchase intentions for packaged tour services. Journal of Travel Research, 47(3): 317-331.

Henseler J, Chin WW. 2010. A comparison of approaches for the analysis of interaction effects between latent variables using partial least squares path modeling. Structural Equation Modeling 17(1): 82-109. 
Henseler J, Ringle CM, Sarstedt M. 2015. A new criterion for assessing discriminant validity in variance-based structural equation modeling. Journal of the Academy of Marketing Science 43(1): 115-135.

Hou J-S, Lin C-H, Morais DB. 2005. Antecedents of attachment to a cultural tourism destination: the case of Hakka and Non-Hakka Taiwanese Visitors to Pei$\mathrm{Pu}$, Taiwan. Journal of Travel Research 44(2): 221-233.

Houston MJ, Rothschild ML. 1978. Conceptual and methodological perspectives in involvement. In Research frontiers in marketing: Dialogues and directions, Jain SC (ed.) American Marketing Association: Chicago; 184-187.

Huang C-Y, Chou C-J, Lin P-C. 2010. Involvement theory in constructing bloggers' intention to purchase travel products. Tourism Management 31(4): 513-526.

Huang Y, Scott N, Ding P, Cheng D. 2012. Impression of Liusanjie: Effect of mood on experience and satisfaction. International Journal of Tourism Research 14(1): 91102.

Hultman M, Skarmeas D, Oghazi P, Beheshti HM. 2015. Achieving tourist loyalty through destination personality, satisfaction, and identification. Journal of Business Research, 68(11): 2227-2231.

Hyun, SS. 2010. Predictors of relationship quality and loyalty in the chain restaurant industry. Cornell Hospitality Quarterly, 51(2): 251-267.

Jin N, Lee S, Lee H. 2015. The effect of experience quality on perceived value, satisfaction, image and behavioral intention of Water Park patrons: new versus repeat visitors. International Journal of Tourism Research 17(1): 82-95.

Kang G-D, James J. 2004. Service quality dimensions: an examination of Grönroos's service quality model. Managing Service Quality 14(4): 266-267.

Kang G-D. 2006. The hierarchical structure of service quality: integration of technical and functional quality. Managing Service Quality 16(1): 37-50.

Kang M, Gretzel U. 2012. Effects of podcast tours on tourist experiences in a national park. Tourism Management 33(2): 440-455.

Kim S-H, Holland S, Han H-S. 2011. A structural model for examining how destination image, perceived value, and service quality affect destination loyalty: a case ctudy of Orlando. International Journal of Tourism Research 15(4): 313-328.

Kim H, Woo E, Uysal M. 2015. Tourism experience and quality of life among elderly tourists. Tourism Management 46(February): 465-476.

Kolar T, Zabkar V. 2010. A consumer-based model of authenticity: an oxymoron or the foundation of cultural heritage marketing? Tourism Management 31(5): 652-664.

Kyle G, Absher J, Norman W, Hammitt W, Jodice L. 2007. A modified involvement scale. Leisure Studies 26(4): 399-427.

Kyle G, Graefe A, Manning R, Bacon J. 2004. Effect of activity involvement and place attachmenton recreationists' perceptions of setting density. Journal of Leisure Research 36(2): 209-231.

Lee T-H, Chang Y S. 2012. The influence of experiential marketing and activity involvement on the loyalty intentions of wine tourists in Taiwan. Leisure Studies 31(1): 103-121. 
Lee J, Graefe AR, Burns RC. 2004. Service quality, satisfaction, and behavioral intention among forest visitors. Journal of Travel \& Tourism Marketing 17(1): 7382.

Lee J, Graefe AR, Burns RC. 2007. Examining the antecedents of destination loyalty in a forest setting. Leisure Sciences 29(5): 463-481.

Lee JS, Lee CK, Choi Y. 2010. Examining the role of emotional and functional values in festival evaluation. Journal of Travel Research 50(6): 695-696.

Loureiro SM, González FJ. 2008. The importance of quality, satisfaction, trust, and image in relation to rural tourist loyalty. Journal of Travel \& Tourism Marketing 25(2): 117-136.

Lu L, Chiu CG, Liu Y. 2015. Authenticity, involvement, and image: Evaluating tourist experiences at historic districts. Tourism Management 50 (October): 85-96.

Lundahl N, Vegholm F, Silver L. 2009. Technical and functional determinants of customer satisfaction in the bank-SME relationship. Managing Service Quality, 19(5): 581-594.

Maher JK, Clark J, Motley DG. 2011. Measuring museum service quality in relationship to visitor membership: The case of a Children's Museum. International Journal of Arts Management 13(2): 29-42.

Martín-Ruiz D, Castellanos-Verdugo M, Oviedo-García MA. 2010. A visitors' evaluation index for a visit to an archaeological site. Tourism Management 31(5): 590-596

Mason MC, Paggiaro A. 2012. Investigating the role of festivalscape in culinary tourism: The case of food and wine events. Tourism Management 33(6): 1329-1336.

McIntyre N. 1989. The personal meaning of participation: Enduring involvement. Journal of Leisure Research 21(2): 167-179.

Miró Foundation (2015). The Foundation. Available from: http://www.fmirobcn.org/fundacio/en_index/ (accessed 20 Feb 2016).

Nowacki MM. 2005. Evaluating a museum as a tourist product using the servqual method. Museum Management and Curatorship 20(3): 235-250.

Nowacki MM. 2009. Quality of visitor attractions, satisfaction, benefits and behavioural intentions of visitors: Verification of a model. International Journal of Tourism Research 11(3): 297-309.

Nunnally JC, Bernstein IH. 1994. The assessment of reliability. Psychometric theory 3, 248-292.

Oh H, Fiore AM, Jeung M. 2007. Measuring experience economy concepts: Tourism applications. Journal of Travel Research 46(2): 119-132.

Oliver RL. 1999. Whence consumer loyalty? Journal of Marketing 63(4): 33-45.

Oliver RL, Bearden WO. 1983. The role of involvement in satisfaction processes. In Advances in consumer research. Series 10, Bagozzi RP, Tybout AM (Eds.) Association for Consumer Research: Provo, UT; 205-255.

Olsen SO, Wilcox J, Olsson U. 2005. Consequences of ambivalence on satisfaction and loyalty. Psychology \& Marketing, 22(3): 247-269.

Özel ÇH, Kozak N. 2012. Motive based segmentation of the cultural tourism market: a study of Turkish domestic tourists. Journal of Quality Assurance in Hospitality \& Tourism, 13(3): 165-186. 
Palau-Saumell R, Forgas-Coll S, Sánchez-García J, Prats-Planagumà L. 2013. Tourist behavior intentions and the moderator effect of knowledge of UNESCO world heritage sites: The case of La Sagrada Familia. Journal of Travel Research 52(3): 364-376.

Palau-Saumell R, Forgas-Coll S, Sánchez-García J, Prats-Planagumà L. 2014. Managing dive centres: SCUBA divers' behavioural intentions. European Sport Management Quarterly 14(4): 422-443.

Parasuraman A, Zeithaml VA, Berry LL. 1988. SERVQUAL: A multiple-item scale for measuring consumer perceptions of service quality. Journal of Retailing 64(1): 1240.

Pearce PL. 2005. Tourist behavior: Themes and conceptual schemes. Channel View Publications: Clevedon, UK.

Petty R, Cacioppo J, Schumann D. 1983. Central and peripheral routes to advertising effectiveness: The moderating role of involvement. Journal of Consumer Research, 10(2): 135-146.

Picasso Museum (2015). About. Available from: http://www.bcn.cat/museupicasso/en/museum/presentation.html (accessed $25 \mathrm{Feb}$ 2016).

Pine BJ, Gilmore JH. 1999. The experience economy. Harvard Business School: Boston, MA.

Prayag G, Hosany S, Odeh K. 2013. The role of tourists' emotional experiences and satisfaction in understanding behavioral intentions. Journal of Destination Marketing \& Management, 2(2), 118-127.

Prentice R, Guerin S, McGugan S. 1998. Learning at a heritage attraction: a case study of discovery as a media product. Tourism Management 19(1): 5-23.

Reichel A, Lowengart O, Milman A. 2000. Rural tourism in Israel: Service quality and orientation. Tourism Management 21(5): 451-459.

Richard M D, Allaway A W. 1993. Service quality attributes and choice behaviour. Journal of Services Marketing 7(1): 59-68.

Quinlan-Cutler S, Carmichael B, Doherty S. 2014. The Inca trail experience: Does the journey matter?. Annals of Tourism Research 45, 152-166.

Samen AAA-E, Akroush MN, Abu-Lail BN. 2013. Mobile SERVQUAL: A comparative analysis of customers' and managers' perceptions. International Journal of Quality and Reliability Management 30(49): 403-425.

Shaffer TR, Sherrell DL. 1997. Consumer satisfaction with health-care services: The influence of involvement. Psychology \& Marketing 14(3): 261-285.

Shen S, Schüttemeyer A, Braun B. 2009. Visitors' intention to visit world cultural heritage sites: an empirical study of Suzhou, China. Journal of Travel \& Tourism Marketing, 26(7), 722-734.

Sheng C-W, Chen M-C. 2012. A study of experience expectations of museum visitors. Tourism Management 33(1): 53-60.

Song, H, Li G, Van der Veen, R, Chen, JL. 2011. Assessing mainland Chinese tourists' satisfaction with Hong Kong using tourist satisfaction index. International Journal of Tourism Research 13(1): 82-96. 
Suh J-C, Yi Y. 2006. When brand attitudes affect the customer satisfaction loyalty relation: The moderating role of product involvement. Journal of Consumer Psychology 16(2): 145-155.

Tan, WK. 2016. Repeat visitation: a study from the perspective of leisure constraint, tourist experience, destination images, and experiential familiarity. Journal of Destination Marketing \& Management. http://dx.doi.org/10.1016/j.jdmm.2016.04.003

Tian-Cole S, Crompton J. 2003. A conceptualization of the relationships between service quality and visitor satisfaction, and their links to destination selection. Leisure Studies 22(1): 65-80.

Tian-Cole S, Crompton, JL, \& Willson, VL. 2002. An empirical investigation of the relationships between service quality, satisfaction and behavioral intentions among visitors to a wildlife refuge. Journal of Leisure Research, 34(1): 1-24.

Tsai, CTS. 2016. Memorable tourist experiences and place attachment when consuming local food. International Journal of Tourism Research. http://dx.doi.org/10.1002/jtr.2070

Wang W, Chen JS, Fan L, Lu J. 2012. Tourist experience and Wetland Parks: A case of Zhejiang, China. Annals of Tourism Research 39(4): 1763-1778.

Wetzels M, Odekerken-Schröder G, Van Oppen C. 2009. Using PLS path modeling for assessing hierarchical construct models: Guidelines and empirical illustration. MIS quarterly 33(1), 177-195.

Williams P, Soutar GN. 2009. Value, satisfaction and behavioral intentions in an adventure tourism context. Annals of Tourism Research, 36(3): 413-438.

Wong IA., \& Tang SLW. 2016. Linking travel motivation and loyalty in sporting events: the mediating roles of event involvement and experience, and the moderating role of spectator type. Journal of Travel \& Tourism Marketing, 33(1), 63-84.

Yoon Y-S, Lee J-S, Lee C-K, (2010). Measuring festival quality and value affecting visitors' satisfaction and loyalty using a structural approach. International Journal of Hospitality Management 29(2): 335-342.

Yuan, JJ., \& Jang, SS. 2008. The effects of quality and satisfaction on awareness and behavioral intentions: Exploring the role of a wine festival. Journal of Travel Research 46(3): 279-288.

Zeitahml VA, Berry LL, Parasaruman A. 1996. The behavioral consequences of service quality. Journal of marketing 60(2): 31-46. 
Table 1. Measurement model: reliability and validity

\begin{tabular}{|c|c|c|c|c|c|}
\hline Constructs & Indicator & $\begin{array}{c}\text { Standardized } \\
\text { Loading } \\
\lambda\end{array}$ & $\begin{array}{c}\text { Cronbach's } \\
\text { Alpha }\end{array}$ & $\begin{array}{c}\text { Composite } \\
\text { Reliability Index } \\
(\mathrm{CRI})\end{array}$ & $\begin{array}{l}\text { Average Variance } \\
\text { Extracted (AVE) }\end{array}$ \\
\hline \multirow{3}{*}{$\begin{array}{l}\text { Behavioural Intentions } \\
\text { (INT) }\end{array}$} & INT1 & 0.790 & \multirow{4}{*}{0.854} & \multirow{3}{*}{0.912} & \multirow{3}{*}{0.776} \\
\hline & INT2 & 0.926 & & & \\
\hline & INT3 & 0.920 & & & \\
\hline \multirow{4}{*}{ Satisfaction (SAT) } & SAT1 & 0.905 & & \multirow{4}{*}{0.947} & \multirow{4}{*}{0.816} \\
\hline & SAT2 & 0.927 & \multirow{3}{*}{0.925} & & \\
\hline & SAT3 & 0.889 & & & \\
\hline & SAT4 & 0.892 & & & \\
\hline Learning Experience & LEA1 & 0.878 & \multirow{2}{*}{0.735} & \multirow{2}{*}{0.883} & \multirow{2}{*}{0.790} \\
\hline Dimensions (LEA) & LEA2 & 0.900 & & & \\
\hline Enjoyment Experience & ENJ1 & 0.929 & \multirow{2}{*}{0.832} & \multirow{2}{*}{0.922} & \multirow{2}{*}{0.856} \\
\hline Dimensions (ENJ) & ENJ2 & 0.922 & & & \\
\hline Evasion Experience & EVA1 & 0.865 & \multirow{2}{*}{0.733} & \multirow{2}{*}{0.881} & \multirow{2}{*}{0.788} \\
\hline Dimensions (EVA) & EVA2 & 0.910 & & & \\
\hline \multirow{6}{*}{ Quality (QUA) } & QUA1 & 0.716 & \multirow{6}{*}{0.849} & \multirow{6}{*}{0.888} & \multirow{6}{*}{0.572} \\
\hline & QUA2 & 0.812 & & & \\
\hline & QUA3 & 0.835 & & & \\
\hline & QUA4 & 0.678 & & & \\
\hline & QUA5 & 0.706 & & & \\
\hline & QUA6 & 0.776 & & & \\
\hline \multirow{3}{*}{$\begin{array}{l}\text { Attraction Involvement } \\
\text { Dimension (ATT) }\end{array}$} & ATT1 & 0.944 & \multirow{3}{*}{0.927} & \multirow{3}{*}{0.953} & \multirow{3}{*}{0.872} \\
\hline & ATT2 & 0.954 & & & \\
\hline & ATT3 & 0.903 & & & \\
\hline \multirow{3}{*}{$\begin{array}{l}\text { Centrality Involvement } \\
\text { Dimension (CEN) }\end{array}$} & CEN1 & 0.893 & \multirow{3}{*}{0.859} & \multirow{3}{*}{0.914} & \multirow{3}{*}{0.780} \\
\hline & CEN2 & 0.917 & & & \\
\hline & CEN3 & 0.838 & & & \\
\hline \multirow{4}{*}{$\begin{array}{l}\text { Self-Expression } \\
\text { Involvement Dimension } \\
\text { (SE) }\end{array}$} & SE1 & 0.838 & \multirow{4}{*}{0.851} & & \\
\hline & SE2 & 0.848 & & 000 & \\
\hline & SE3 & 0.861 & & 0.899 & 0.691 \\
\hline & SE4 & 0.776 & & & \\
\hline
\end{tabular}

Table 2. Discriminant validity

\begin{tabular}{lccccccccc}
\hline Construct & 1 & 2 & 3 & 4 & 5 & 6 & 7 & 8 & 9 \\
\hline 1.ATT & 0.943 & 0.861 & 0.771 & 0.316 & 0.537 & 0.571 & 0.584 & 0.624 & 0.634 \\
2.CEN & 0.772 & 0.883 & 0.847 & 0.320 & 0.490 & 0.516 & 0.508 & 0.527 & 0.594 \\
3.SE & 0.690 & 0.731 & 0.831 & 0.304 & 0.453 & 0.571 & 0.584 & 0.513 & 0.559 \\
4.QUA & 0.279 & 0.271 & 0.260 & 0.756 & 0.685 & 0.476 & 0.508 & 0.663 & 0.620 \\
5.LEA & 0.447 & 0.392 & 0.364 & 0.542 & 0.889 & 0.738 & 0.727 & 0.817 & 0.771 \\
6.ENJ & 0.502 & 0.438 & 0.481 & 0.402 & 0.580 & 0.925 & 0.874 & 0.753 & 0.714 \\
7.EVA & 0.484 & 0.428 & 0.466 & 0.403 & 0.542 & 0.685 & 0.888 & 0.682 & 0.672 \\
8.SAT & 0.580 & 0.473 & 0.461 & 0.580 & 0.674 & 0.662 & 0.567 & 0.904 & 0.897 \\
9.INT & 0.561 & 0.503 & 0.474 & 0.561 & 0.616 & 0.606 & 0.539 & 0.805 & 0.881 \\
\hline
\end{tabular}

Note 1: Figures in the diagonal present the squared root of the AVE values. Values below the diagonal represent the constructs' correlations. Values above the diagonal are the HTMT values. 
Table 3. Results of the structural model

\begin{tabular}{lcc}
\hline Hypothesis & $\beta$ & $t$-value \\
\hline H1: Satisfaction $\rightarrow$ Behavioural intentions & 0.574 & $19.335^{*}$ \\
H2: Experience $\rightarrow$ Satisfaction & 0.477 & $16.334^{*}$ \\
H3: Experience $\rightarrow$ Behavioural intentions & 0.132 & $4.429^{*}$ \\
H4: Quality $\rightarrow$ Satisfaction & 0.275 & $10.081^{*}$ \\
H5: Quality $\rightarrow$ Behavioural intentions & 0.087 & $3.353^{*}$ \\
H6: Involvement $\rightarrow$ Satisfaction & 0.180 & $7.041^{*}$ \\
H7: Involvement $\rightarrow$ Behavioural intentions & 0.144 & $5.644^{*}$ \\
Moderating effect of Involvement & $\beta$ & $t$-value \\
H8: Involvement X Experience $\rightarrow$ Satisfaction & -0.056 & $3.160^{*}$ \\
H9: Involvement X Quality $\rightarrow$ Satisfaction & -0.085 & $5.039^{*}$ \\
$R^{2}$ & & \\
$\mathrm{R}^{2}($ SAT $)=0.681$ & & \\
$\mathrm{R}^{2}(\mathrm{INT})=0.644$ & & \\
$Q^{2}$ & & \\
$\mathrm{Q}^{2}(\mathrm{SAT})=0.522$ & & \\
$\mathrm{Q}^{2}(\mathrm{INT})=0.526$ & & \\
\hline
\end{tabular}

Note $1: * p<0.01$; 


\section{Appendix A. Constructs, Scale Items and Sources}

\begin{tabular}{|c|c|c|}
\hline Construct & Items & Source \\
\hline $\begin{array}{l}\text { Behavioural } \\
\text { Intentions (INT) }\end{array}$ & $\begin{array}{l}\text { INT1. Willingness to revisit. } \\
\text { INT2. Willing to recommend to others. } \\
\text { INT3. Positive word-of-mouth to others. }\end{array}$ & Lee et al. (2007). \\
\hline Satisfaction (SAT) & $\begin{array}{l}\text { SAT1. I am satisfied with the visit. } \\
\text { SAT2. I am satisfied with the services } \\
\text { received. } \\
\text { SAT3. My expectations of the museum have been } \\
\text { fulfilled. } \\
\text { SAT4. In general, I'm satisfied with the visit to the } \\
\text { museum. }\end{array}$ & $\begin{array}{l}\text { Forgas-Coll et al. } \\
\text { (2012). }\end{array}$ \\
\hline $\begin{array}{l}\text { Learning Experience } \\
\text { Dimensions (LEA) }\end{array}$ & $\begin{array}{l}\text { LEA1. I expanded my understanding of the artist } \\
\text { paintings. } \\
\text { LEA2. I gained information and knowledge about the } \\
\text { artist. }\end{array}$ & $\begin{array}{l}\text { Kang and Gretzel } \\
(2012)\end{array}$ \\
\hline $\begin{array}{l}\text { Enjoyment } \\
\text { Experience } \\
\text { Dimensions }(\mathrm{ENJ})\end{array}$ & $\begin{array}{l}\text { ENJ1. I had fun with the visit. } \\
\text { ENJ2. I enjoyed being in the museum. }\end{array}$ & $\begin{array}{l}\text { Kang and Gretzel } \\
(2012)\end{array}$ \\
\hline $\begin{array}{l}\text { Evasion Experience } \\
\text { Dimensions (EVA) }\end{array}$ & $\begin{array}{l}\text { EVA1. I got away from it all. } \\
\text { EVA2. It has been emotional because I felt like I was in } \\
\text { another world. }\end{array}$ & $\begin{array}{l}\text { Kang and Gretzel } \\
(2012)\end{array}$ \\
\hline Quality (QUA) & $\begin{array}{l}\text { QUA1. Employees of the museum have provided me } \\
\text { with good service. } \\
\text { QUA2. The exhibits are well explained to the visitor. } \\
\text { QUA3. The visitor receives enough information to enjoy } \\
\text { a visit. } \\
\text { QUA4. The museum provides good services. } \\
\text { QUA5. I believe that the proposed signaling of the } \\
\text { exhibitions is well arranged for the visitor. }\end{array}$ & $\begin{array}{l}\text { Martin-Ruíz et al. } \\
\text { (2010). }\end{array}$ \\
\hline
\end{tabular}


Attraction

Involvement

Dimension (ATT)

Centrality

Involvement

Dimension (CEN)

Self-Expression

Involvement

Dimension (SE)
QUA6. The museum knows how to use the facilities to make a visit more interesting.

ATT1. Art is important to me.

Chang and

Gibson (2011).

ATT2. Art is one of the things that makes me enjoy.

ATT3. Art allows me to relax my daily activities.

CEN1. Art exhibitions occupy an important part of my leisure time.

CEN2. I enjoy talking about art with my acquaintances.

CEN3. Many of my acquaintances like art.

SE1. My art-related activities explain who am I.

SE2. When I visit an art exhibition is when I can really

be myself.

SE3. You can tell a lot about a person by seeing them visiting an art exhibition.

SE4. When I participate in art activities others, such as family/friends/aqcuaintances, see me the way I want them to see me.
Chang and Gibson (2011). 


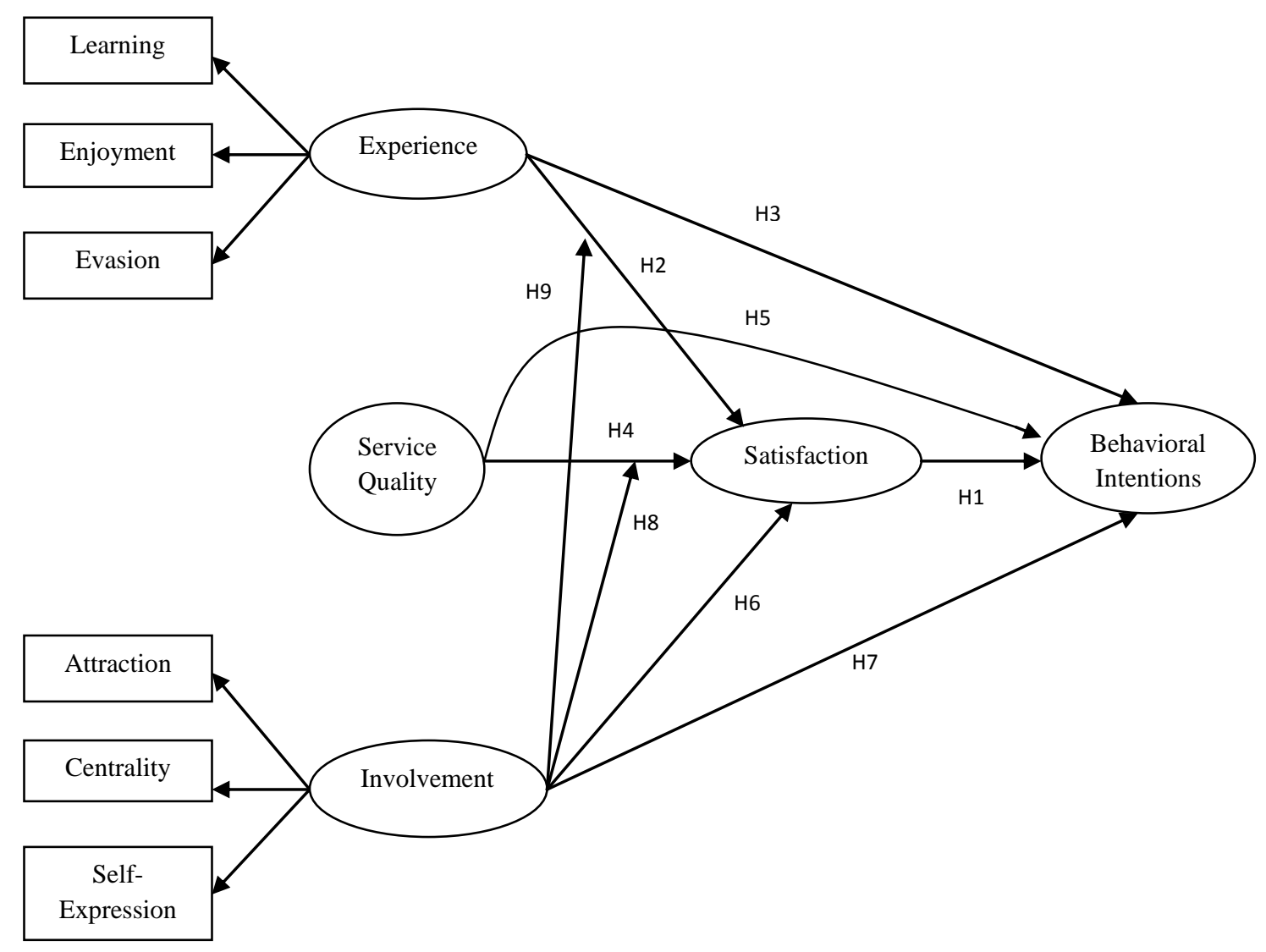

Figure 1. A conceptual research model 